\title{
STRATEGI PEMASARAN PT. HUAWEI DALAM MENINGKATKAN PANGSA PASAR
}

\author{
Nicolas Septian \\ Program Studi Magister Manajemen Universitas Tarumanagara \\ septian.nicolas@gmail.com \\ Chairy \\ Program Studi Magister Manajemen Universitas Tarumanagara
}

\begin{abstract}
In this era, everyone is very dependent on cellphones, especially smart phones. With the fourth most populous population in the world and the low adoption rate of smart phones, the smartphone market is an attractive market for local vendors and international vendors. As one of the world's biggest vendors, Huawei has difficulty facing competition in the Indonesian market. Therefore, the purpose of this thesis is to arrange and suggest a proper marketing strategy for the company. Data collection methods were interviews and observations. Writing starts from the analysis of external, internal, and industrial environments, SWOT analysis, and BCG matrix analysis.
\end{abstract}

Abstrak : Di era ini, semua orang sangat bergantung pada ponsel, terutama ponsel pintar. Dengan populasi terpadat keempat di dunia dan tingkat adopsi yang rendah dari ponsel pintar, pasar smartphone adalah pasar yang menarik bagi vendor lokal dan vendor internasional. Sebagai salah satu vendor terbesar di dunia, Huawei mengalami kesulitan menghadapi persaingan di pasar Indonesia. Oleh karena itu, tujuan dari tesis ini adalah untuk mengatur dan menyarankan strategi pemasaran yang tepat untuk perusahaan. Metode pengumpulan data adalah wawancara dan observasi. Penulisan dimulai dari analisis lingkungan eksternal, internal, dan industri, analisis SWOT, dan analisis matriks BCG.

Keywords: smartphone, SWOT matrix, BCG matrix

\section{PENDAHULUAN}

David and David (2017) mengungkapkan bahwa perkembangan teknologi dipengaruhi oleh internet. Internet semakin dibutuhkan dalam kehidupan sehari-hari, masih menurut David and David (2017) Internet telah merubah sifat dari peluang dan ancaman dengan mengubah siklus hidup produk, meningkatkan kecepatan dalam distribusi produk, dan menciptakan produk dan jasa baru. Menurut hasil survey APJII (Asosiasi Penyelenggara Jasa Internet Indonesia), pada tahun 2017 perangkat atau gadget yang dimiliki oleh masyarakat Indonesia untuk mengakses internet dibagi menjadi dua bagian yaitu komputer atau laptop dan ponsel pintar atau tablet. Dari hasil survey, masyarakat Indonesia memiliki komputer atau laptop dengan persentase $25.72 \%$ dan ponsel pintar atau tablet dengan persentase $50,08 \%$. Menurut hasil survey pada tahun 2010, penduduk Indonesia dominan berada di rentang umur 15 - 64 tahun, yang mana itu adalah usia produktif atau usia kerja. Pada usia produktif, kebutuhan akan ponsel pintar yang bagus, handal, dan ramah kantong menjadi tinggi. Berdasarkan data yang di publikasikan oleh International Data Corporation (IDC) hingga kuartal II-2016, Pasar smartphone di Indonesia, lima besar merek ponsel pintar dikuasai oleh Samsung, Oppo, Asus, Advan, dan Lenovo. Sebagai salah satu vendor besar dunia, Huawei memiliki pangsa pasar yang kecil di pasaran Indonesia seperti dilaporkan oleh IDC dengan pangsa pasar di bawah 6\%. Maka dari itu, Huawei berambisi untuk meningkatkan pangsa pasarnya menjadi $10 \%$. Dengan menggunakan penelitian kualitatif 
yang merupakan penelitian yang digunakan untuk menyelidiki, menemukan, menggambarkan, dan menjelaskan kualitas atau keistimewaan dari pengaruh sosial yang tidak dapat dijelaskan, diukur atau digambarkan melalui pendekatan kuantitatif (Saryono, 2010:1). Sugiyono (2011:15), mendefinisikan metode penelitian kualitatif adalah metode penelitian yang berlandaskan pada filsafat postpositivism, digunakan untuk meneliti pada kondisi objek yang alamiah, (sebagai lawannya eksperimen)

\section{LANDASAN TEORI}

Analisis Lingkungan

Analisis lingkungan dibagi menjadi tiga yaitu: analisis lingkungan internal, analisis lingkungan eksternal, dan analisis lingkungan industri. Analisis lingkungan eksternal dapat digunakan untuk mengantisipasi peluang. Analisis tersebut cukup penting karena lingkungan eksternal merupakan suatu yang tidak bisa dikendalikan oleh perusahaan yaitu sesuatu yang bergerak dinamis (Hitt, Ireland, and Hoskisson, 2015). Analisis lingkungan eksternal terdiri dari lima faktor yaitu: (1)Faktor ekonomi; (2)Faktor sosial; (3)Faktor politik; (4)Faktor teknologi; dan (5)Faktor ekologi. Pada faktor ekonomi: Pearce II and Robinson (2014) mengatakan bahwa faktor ekonomi berkaitan dengan sifat dan arah perekonomian dimana suatu perusahaan beroperasi. Salah satu faktor krusial pada faktor ekonomi adalah inflasi. Menurut Samuelson and Nordhaus (2009:683) "Inflation occurs when the general level of prices is rising", atau dengan kata lain inflasi terjadi ketika tingkat harga-harga secara umum meningkat. Pada faktor sosial: Menurut David and David (2017) tren sosial, budaya, demografi, dan lingkungan membentuk seseorang. Tren yang baru menciptakan konsumen yang baru juga yang mungkin berbeda dengan sebelumnya dan konsekuensinya adalah kebutuhan akan yang berbeda pula. Pada faktor politik: politik dan sikap berpolitik memiliki peranan penting dalam bisnis. Menurut Salvadori (1950) terdapat empat bidang ilmu politik yaitu: Teori politik, Lembaga politik, Partai, dan Hubungan Internasional. Pada faktor teknologi: menurut Pearce II and Robinson (2014) untuk menghindari keusangan dan meningkatkan inovasi, suatu perusahaan harus menyadari perubahan teknologi, kuasi ilmu pengetahuan yang mencoba meramalkan kemajuan dan memperkirakan dampaknya terhadap operasi suatu organisasi dikenal sebagai peramal teknologi (technological forecasting). Pada faktor ekologi: mengacu pada hubungan antara manusia dan makhluk hidup lainnya, serta udara, tanah, dan air (faktor lingkungan) yang mendukungnya. Ancaman terhadap ekologi yang mendukung kehidupan manusia dalam komunitas industri secara umum disebut polusi.

Menurut Daft and Marcie (2015), lingkungan internal adalah faktor-faktor yang ada di dalam perusahaan. Analisis lingkungan internal bertujuan untuk mengetahui seberapa jauh kemampuan internal perusahaan dengan memerhatikan juga hasil analisa lingkungan eksternal. Analisis lingkungan internal terdiri dari empat faktor yaitu: (1)Faktor Sumber daya manusia; (2)Faktor penggunaan teknologi; (3)Faktor logistik; (4)Faktor pengadaan barang. Pada faktor SDM: Katz and Green (2011) menyatakan ada beberapa hal yang perlu diperhatikan dalam manajemen sumber daya manusia pada sebuah perusahaan antara lain: rekrutmen karyawan dan pelatihan karyawan. Pada faktor penggunaan teknologi: Penggunaan teknlogi sudah berlaku sejak zaman dahulu. Namun hal ini tidak disadari secara langsung oleh manusia. Teknologi juga sangat mempengaruhi masyarakat luas dengan berbagai cara di berbagai bidang. Pada faktor logistik: Menurut Wheelan, Hunger, and David (2015) Strategi logistik berkaitan dengan proses keluar masuknya produk ke dalam proses manufakturing. Tiga tren terkait strategi ini adalah : terpusat, alih daya, dan penggunaan internet. Pada faktor pengadaan barang: Keragaman pemasok adalah satu keuntungan yang mungkin tidak ada harganya tetapi ini sering kali terlewat oleh pembeli bisnis.

Analisis lingkungan industri atau Five Forces Porter bertujuan untuk membantu analisis terkait lingkungan pada industri ponsel. Menurut Porter (1997) Analisis lingkungan industri terdiri dari lima faktor yaitu: (1)Persaingan diantara perusahaan sejenis; (2)Kekuatan 
pembeli; (3)Kekuatan supplier; (4)Hambatan dari penantang baru; dan (5)Hambatan dari produk pengganti. Pada persaingan diantara perusahaan sejenis: persaingan dikalangan anggota industri biasanya berpengaruh diantara lima (5) kekuatan. Pada kekuatan pembeli: pembeli juga dapat memaksa turunnya harga sebuah produk, menuntut kualitas produk yang lebih baik atau pelayanan yang lebih, dan mengadu pemasok. Pada kekuatan supplier: pemasok memanfaatkan kekuatan tawar menawar dari para anggota dengan menaikan harga atau menurunkan kualitas barang atau jasa yang dijualnya. Pada hambatan dari penantang baru: Pendatang baru didalam suatu industri membawa kapasitas baru sehingga memiliki keinginan untuk merebut bagian atau pangsa pasar dengan sumber daya yang substansial. Pada Hambatan dari produk pengganti: Dengan menetapkan barang dengan harga yang tinggi, produk maupun jasa sejenis atau substitusi membatasi potensi suatu industri.

\section{Matriks SWOT}

Menurut Pearce II \& Robinson (2014), Analisis SWOT merupakan teknik historis yang terkenal di mana para manajer menciptakan gambaran umum secara cepat mengenai situasi startegis perusahaan. Analisis ini didasarkan pada asumsi bahwa strategi yang efektif diturunkan dari "kesesuaian" yang baik antara sumber daya internal perusahaan (kekuatan dan kelemahan) dengan situasi eksternal perusahaan (peluang dan ancaman).

Peluang (opportunity) merupakan situasi utama yang menguntungkan dalam lingkungan eksternal suatu perusahaan. Kecenderungan utama merupakan salah satu sumber peluang. Identifikasi atas segmen pasar yang sebelumnya terlewatkan, perubahan dalam kondisi persaingan atau regulasi, perubahan teknologi, dan membaiknya hubungan dengan pembeli ataupun pemasok merupakan sebuah peluang bagi perusahaan. Ancaman (threat) merupakan situasi utama yang tidak menguntungkan dalam lingkungan eksternal suatu perusahaan. Ancaman merupakan penghalang utama bagi perusahaan dalam mencapai posisi saat ini atau posisi yang diinginkan. Contoh sebuah ancaman bagi suatu perusahaan adalah masuknya pesaing baru, melambannya pertumbuhan pasar, meningkatnya kekuatan tawar menawar dari pembeli atau pemasok utama, perubahan teknologi, dan adanya pembaharuan atau revisi peraturan oleh regulator. Kekuatan (strength) adalah sumber daya atau kapabilitas yang dikendalikan oleh atau tersedia bagi perusahaan yang membuat perusahaan relatif lebih unggul dibandingkan oleh pesaingnya dalam memenuhi kebutuhan pelanggan yang akan dilayaninya. Kekuatan muncul dari sumber daya dan kompetensi yang tersedia bagi perusahaan. Kelemahan (weakness) merupakan keterbatasan atau kekurangan dalam satu atau lebih sumber daya atau kapabilitas suatu perusahaan relatif terhadap pesaingnya, yang menjadi hambatan dalam memenuhi kebutuhan pelanggan secara efektif.

Menurut David and David (2017) matrik SWOT adalah sebuah alat pencocokan yang penting yang membantu para manajer mengembangkan empat jenis strategi, yaitu strategi SO (kekuatan peluang), strategi WO (kelemahan peluang), strategi ST (kekuatan ancaman), dan strategi WT (kelemahan ancaman).

Strategi SO memanfaatkan kekuatan internal perusaan untuk menarik keuntungan dari peluang eksternal. Strategi WO bertujuan untuk memperbaiki kelemahan internal dengan cara mengambil keuntungan dari peluang eksternal. Strategi ST menggunakan kekuatan sebuah perusahaan untuk menghindari atau mengurangi dampak ancaman eksternal. Strategi WT merupakan taktik defensif yang diarahkan untuk mengurangi kelamahan internal serta menghindari ancaman eksternal.

\section{Matriks BCG}

Tujuan dari matriks BCG adalah mengetahui produk manakah yang layak mendapat perhatian dan dukungan dana agar produk tersebut dapat bertahan dan menjadi kontributor terhadap kinerja perusahaan dalam jangka panjang. Matriks BCG digunakan untuk memahami pasar, optimasi portofolio dan alokasi sumber daya yang efektif. Untuk 
memahami matriks BCG, kita perlu memahami bagaimana pangsa pasar dan pertumbuhan pasar saling berhubungan. Pangsa pasar adalah persentase dari total pasar yang sedang dilayani oleh perusahaan, baik dalam hal pendapatan atau dalam satuan volume. Semakin tinggi pangsa pasar, semakin tinggi proposi pasar yang akan dikontrol.

Matriks BCG mengasumsikan bahwa jika kita menikmati pangsa pasar yang tinggi, maka kita akan menghasilkan uang. Pertumbuhan pasar digunakan sebagai ukuran dari daya tarik pasar. Jika pasar mengalami pertumbuhan pasar tinggi dari total perkembangan pasar, maka akan relatif mudah bagi bisnis untuk menambah keuntungan mereka, bahkan jika pangsa pasar mereka tetap stabil. Sebaliknya kondisi pangsa pasar yang rendah tidak menambah keuntungan, namun kondisi pangsa pasar yang tinggi belum tentu juga menguntungkan jika tidak ada upaya memberikan diskon secara agresif.

Menurut Wheelan, Hunger, and David (2015), keuntungan menggunakan matriks ini adalah matriks BCG mudah untuk dihitung dan diaplikasikan. Sedangkan keterbatasan matriks ini menurut mereka adalah: (1)Penggunaan nilai tertinggi dan terendah untuk membentuk empat kategori terlalu sederhana; (2)Hubungan antara pangsa pasar dan keuntungan (pertumbuhan pasar) menimbulkan pertanyaan. Bisnis yang low share juga bisa memberi keuntungan; (3)Tingkat pertumbuhan hanya satu aspek pada daya tarik industri; (4)Lini produk atau bisnis unit hanya dibandingkan dengan pemimpin pasar; (5)Kompetitor yang kecil dengan pertumbuhan yang cepat tidak diperhitungkan; (6)Pangsa pasar hanya satu aspek dari posisi kompetitif

Matriks BCG terdiri dari matriks yang berukuran 2 baris $\mathrm{x} 2$ kolom atau terdiri dari 4 sel (4 kuadran). 4 sel tersebut pada dasarnya mewakili 4 kategori portofolio produk perusahaan dari 2 dimensi klasifikasi bisnis unit yaitu Relative Market Share (pangsa pasar relatif) dan Market Growth Rate (tingkat pertumbuhan pasar). Kategori-kategori tersebut masing-masing diwakili oleh Bintang (Star), Sapi Perah (Cash Cows), Anjing (Dogs) dan Tanda Tanya (Question Marks). Bintang (stars) melambangkan bisnis-bisnis yang berada dalam pasar besar yang tumbuh pesat. Bisnis-bisnis ini mencerminkan peluang jangka panjang terbaik (pertumbuhan dan profitabilitas) dalam portofolio perusahaan. Bisnis-bisnis tersebut membutuhkan investasi yang substansial untuk mempertahankan (dan memperluas) posisi yang dominan dalam suatu pasar yang bertumbuh. Menurut David and David (2017), strategi yang tepat untuk diaplikasikan pada bisnis dalam kategori ini adalah penetrsi pasar, pengembangan pasar, pengembangan produk, dan forward, backward, horizontal integration. Sapi perah (cash cow) adalah bisnis-bisnis yang memilih pangsa pasar besar dalam pasar atau industri dengan pertumbuhan yang rendah. Karena posisi kompetitifnya yang kuat dan kebutuhan akan reinvestasi yang minimum, bisnis-bisnis ini seringkali menghasilkan kas melebihi kebutuhannya. Menurut David and David (2017), strategi yang tepat untuk diaplikasikan pada bisnis dalam kategori ini adalah penetrsi pasar, pengembangan pasar, pengembangan produk, dan forward, backward, horizontal integration. Bisnis-bisnis dengan pangsa dan pertumbuhan pasar yang rendah termasuk dalam kategori anjing (dog) dalam portofolio perusahaan. Menghadapi pasar dewasa dengan kompetisi yang intens dan margin laba yang rendah, bisnis-bisnis semacam ini dikelola untuk arus kas jangka pendek (misalnya melalui pemotongan biaya habis-habisan) guna melengkapi kebutuhan sumber daya tingkat korporat. Menurut David and David (2017), strategi yang tepat untuk diaplikasikan pada bisnis dalam kategori ini adalah likuidasi, divestasi, dan dipangkas melalui rentrenchment. Tanda tanya (question marks) adalah bisnis-bisnis yang tingkat pertumbuhannya tinggi sehingga memiliki daya tarik yang besar, namun pangsa pasarnya rendah sehingga membuat potensi labanya menjadi tidak pasti. Tanda tanya adalah "penelan" kas karena pertumbuhannya yang pesat menimbulkan kebutuhan kas yang tinggi, sedangkan pangsa pasarnya kecil menyebabkan kas yang dihasilkan rendah. Menurut David and David (2017) strategi yang tepat untuk diaplikasikan pada bisnis dalam kategori ini adalah penetrasi pasar, pengembangan pasar atau produk, dan divestiture. 


\section{ANALISIS DAN PEMBAHASAN}

Analisis lingkungan eksternal

Berdasarkan analisis lingkungan eksternal berikut adalah peluang bagi perusahaan yang terdiri dari: (1)Penurunan nilai suku bunga oleh Bank Indonesia; (2)Perubahan pola perilaku konsumen ponsel pintar di Indonesia; (3)Gen-Z yang memiliki pengaruh dalam menentukan pembelian pada suatu keluarga; (4)Perkembangan teknologi pada ponsel pintar yang sangat cepat; (5)Trend produk ponsel pintar yang ramah lingkungan. Sedangkan ancaman yang terdiri dari: (1)Laju PDB Indonesia pada bidang jasa informasi dan komunikasi yang menunjukkan trend menurun; (2)Karakteristik tingkat inflasi Indonesia yang tidak stabil; (3)Penerapan aturan TKDN pada industri ponsel pintar.

Analisis lingkungan Internal

Berdasarkan analisis lingkungan internal berikut adalah kekuatan bagi perusahaan yang terdiri dari: (1)Mempunyai proses rekrutmen karyawan yang baik; (2)Mempunyai materi dan proses pelatihan terpusat; (3)Penggunaan teknologi OWS (Operation Web Service) pada manajemen perusahaan; (4)Manajemen logistik yang terpusat dan terpadu; Memiliki pemasok yang beragam. Adapun yang menjadi kelemahan terdiri dari: (1)Sebagian besar karyawan bukan karyawan permanen; (2)Waktu proses persetujuan multi departemen pada proses pengadaan barang yang lama; (3)Proses P2P (Procurement to Payment) yang lama

Analisis Matriks SWOT

Setelah didapatkan apa saja yang menjadi kekuatan, kelemahan, peluang, dan ancaman bagi perusahaan, maka dengan menggunakan matriks SWOT, penulis menyusun strategi SO, WO, ST, dan WT yang terdiri dari: Strategi SO terdiri dari: (1)Merekrut ahli pemasaran lokal yang handal $(\mathrm{S} 1, \mathrm{O} 2)$; (2)Merekrut engineer yang handal untuk menghasilkan lebih banyak paten teknologi (S1,O4); (3)Memperkuat proses logistik untuk menjamin ketersediaan produk di pasaran $(\mathrm{S} 4, \mathrm{O} 2)$; (4)Menawarkan harga terbaik untuk supplier sehingga mereka memiliki keterikatan dengan perusahaan (S5,O1). Strategi WO terdiri dari: (1)Memberikan status permanen untuk engineer yang sudah senior $(\mathrm{W} 1, \mathrm{O} 4)$; (2)Mempercepat proses P2P sehingga cash flow supplier tidak terganggu (W3,O1). Strategi ST terdiri dari: (1)Melakukan perekrutan tenaga kerja lokal (S1,T3); (2)Memberikan pelatihan yang komprehensif pada tenaga kerja lokal (S2,T3); (3)Memperkuat basis data supplier (S5,T1). Strategi WT terdiri dari: (1)Memberikan status permanen untuk karyawan yang memiliki kontribusi baik bagi perusahaan (W1,T1); (2)Memberikan status permanen untuk tenaga kerja lokal (W1,T3)

Analisis Lingkungan Industri

Berdasarkan analisis lingkungan industri, faktor seperti persaingan diantara perusahaan sejenis, kekuatan pembeli, dan hambatan dari kompetitor baru yang tinggi pada industri ponsel pintar sehingga industri ini bisa dibilang kurang menarik. Walaupun industri ponsel di Indonesia kurang menarik, tetapi hal itu tidak mengurangi minat para vendor untuk bersaing didalamnya karena besarnya pasar ponsel di Indonesia. Hal ini dibuktikan dengan meningkatnya pengapalan ponsel di Indonesia pada H1 2018. Selain itu kegemaran masyarakat Indonesia yang mengganti ponsel mereka dalam waktu kurang dari dua tahun membuat pasar ponsel menjadi pasar yang besar.

Analisis Matriks BCG

Pada analisis matriks BCG, kita membutuhkan data pangsa pasar relatif dan tingkat pertumbuhan pasar. Pangsa pasar relatif bisa dihitung dengan menggunakan rumusan sebagai berikut: 
Sedangkan untuk tingkat pertumbuhan pasar bisa dihitung dengan menggunakan rumusan sebagai berikut:

Sehingga kita bisa mendapatkan Growth Rate: $\frac{\text { Present }- \text { Past) }}{\text { Past }}$ untuk matriks BCG seperti tabel berikut:

Tabel 1. Data matriks BCG

\begin{tabular}{|c|c|c|}
\hline Vendor & Market Share relative & Market Growth rate \\
\hline Samsung & 1 & $10.74 \%$ \\
\hline Vendor Lokal & 0.56961 & $-43.16 \%$ \\
\hline Xiaomi & 0.37216 & $286.03 \%$ \\
\hline Oppo & 0.33133 & $164.16 \%$ \\
\hline Asus & 0.22289 & $2.80 \%$ \\
\hline Huawei & 0.04552 & $56.84 \%$ \\
\hline
\end{tabular}

Sehingga matriks BCG bisa digambarkan sebagai berikut:

Gambar1. Matriks BCG Pasar Ponsel

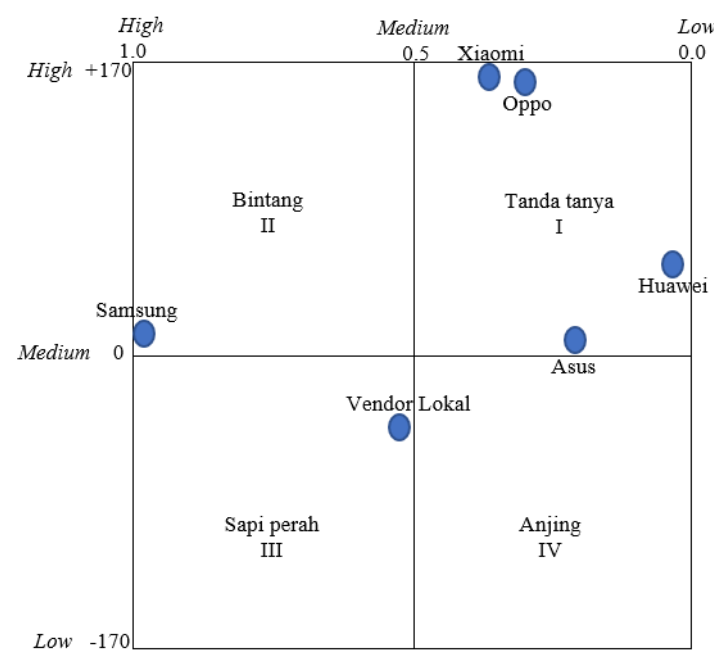

Berdasarkan analisis matriks BCG, Huawei berada di posisi kuadran I yaitu tanda tanya. Hal ini mencerminkan bahwa Huawei memiliki pertumbuhan pasar yang besar tetapi memiliki pangsa pasar yang kecil. Adapun strategi yang disarankan untuk digunakan oleh Huawei sebagai vendor yang berada di posisi tanda tanya adalah strategi penetrasi pasar. Kelima pedoman ini menunjukkan kapan penetrasi pasar menjadi strategi yang sangat efektif: (1)Ketika pasar saat ini tidak jenuh dengan produk atau layanan tertentu; (2)Ketika tingkat penggunaan pelanggan saat ini dapat ditingkatkan secara signifikan; (3)Ketika pangsa pasar pesaing utama telah menurun sementara penjualan industri total telah meningkat; (4)Ketika korelasi antara penjualan dan pengeluaran pemasaran telah tinggi secara historis; (5)Ketika peningkatan skala ekonomi memberikan keunggulan kompetitif yang besar.

Strategi penetrasi lebih disarankan untuk dilakukan karena melihat analisis dari lingkungan internal, lingkungan eksternal, dan lingkungan industri, strategi ini sangat cocok di terapkan oleh Huawei. Dengan faktor lingkungan internal seperti proses rekrutmen yang baik, Huawei disarankan untuk merekrut tenaga pemasaran yang handal sehingga eksposur produk Huawei semakin besar dan brand knowledge Huawei di mata konsumen Indonesia semakin baik. Pada faktor lingkungan eksternal seperti Gen $\mathrm{Z}$ yang menjadi penentu pembelian dalam suatu keluarga, Huawei bisa melakukan penetrasi pasar dengan menawarkan inovasi-inovasi yang lebih baik dari pada kompetitor kepada calon konsumen terutama Gen Z. Penelitian yang dilakukan McCrindle menemukan, ada sekitar dua miliar penduduk dunia yang tergolong ke dalam generasi Z. Mengenal internet sejak kecil membuat 
generasi ini cenderung FOMO (Fear of Missing Out) alias cemas akan ketertinggalan dari yang lain. Sehingga Huawei dengan banyaknya paten yang telah mereka miliki, memiliki peluang yang besar untuk menargetkan konsumen Gen Z.

\section{KESIMPULAN}

Dari hasil analisa bab sebelumnya, berikut adalah kesimpulan yang bisa diambil oleh penulis adalah strategi yang dijalankan Huawei dalam pengembangan dan berkompetisi di pasar ponsel pintar di Indonesia menggunakan analisis matriks BCG yaitu:

- Berdasarkan analisa matriks BCG, Huawei berada pada posisi kuadran I yaitu tanda tanya. Strategi yang tepat untuk posisi kuadran I atau tanda tanya adalah penetrasi pasar, pengembangan pasar atau produk, dan divestasi. Penulis merekomendasikan strategi penetrasi pasar sebagai strategi utama yang harus diperhatikan oleh perusahaan karena strategi lain seperti pengembangan produk dan pasar sudah dilakukan oleh perusahaan. Tetapi untuk strategi divestasi tidak harus dilakukan karena perusahaan berkeinginan untuk terus berpartisipasi dalam industri ponsel.

\section{DAFTAR PUSTAKA}

Daft, L. Richard \& Marcie, Dorothy (2015), Understanding Management (9 ${ }^{\text {th }}$ ed.), SouthWestern Publishing Co.

David, R. Fred \& David, Forest R. (2017), Strategic Management: Concept and Cases (16 ${ }^{\text {th }}$ ed.), New Jersey: Pearson

Hitt, Ireland, \& Hoskisson (2015), Strategic Management: Concept and Cases: Competitiveness and Globalization $\left(11^{\text {th }} \mathrm{ed}\right.$.), Stamford CENGAGE Learning

Katz, J. \& Green, R. (2011), Entrepreneural Small Business ( $3^{\text {rd }}$ ed.). New York: McGrawHill

Kotler, Philip \& Keller, Kevin Lane (2016), Marketing Management (15 ${ }^{\text {th }}$ ed.), New Jersey, USA: Prentice Hall

Pearce II, John A., \& Robinson, Richard (2014), Strategic Management:Formulation, Implementation and Control.(14 ${ }^{\text {th }}$ ed.), McGraw-Hill

Porter, Michael E. (1997), Competitive Strategy: Techniques for Analizing Industries and Competitors, New York: The Free Press (Analisis lingk Industri)

Salvadori, Massimo (1950), Contemporary Political Science, UNESCO

Samuelson, Paul A. \& Nordhaus William D. (2009), Economics (19 ${ }^{\text {th }}$ ed.). McGraw-Hill

Saryono (2010), Metodologi Penelitian Kualitatif dalam Bidang Kesehatan, Yogyakarta: Nuha Medika.

Sugiyono (2011), Metode Penelitian Pendidikan Pendekatan Kuantitatif, Kualitatif, dan $R \& D$, Bandung: Alfabeta

Wheelan, Thomas L., Hunger, David J., Hoffman, Alan N., \& Bamford, Charles E. (2015), Strategic Management \& Business Policy $\left(14^{\text {th }}\right.$ ed. $)$, Pearson 
